\title{
PENDEKATAN KONTEKSTUAL DALAM PEMBELAJARAN MENULIS DI SEKOLAH DASAR (Action Research di Kelas Tinggi Sekolah Dasar)
}

\author{
Zulela MS \\ Jurusan PGSD FIP Universitas Negeri Jakarta KAMPUS E \\ Jln Setia Budi I/1Jakarta Selatan, \\ Email: zulelams@yahoo.co.id.
}

\begin{abstract}
The purpose of this classroom action research was to improve narration writing skills trough contextual approach in the fifth grade elementary schools' students. The classroom action conducted in two cycles. The subjects were fifth grade elementary schools' student of SD 04 Karet Setiabudi south Jakarta. Data was collected using observation, and narration writing test. The analizet data was qualitative data, enhanced with narration writing test evaluation, in the context of measuring effect of implemented action to narration writing skills. Result found that application of contextual approach with variety method and relevant complimentary instrument improved narrations writing skills of fifth grade elementary schools' student. Keywords: writing, contextual approach, elementary school.
\end{abstract}

ABSTRAK

Penelitian tindakan kelas ini bertujuan untuk meningkatkan kemampuan menulis karangan narasi siswa siswa kelas V SD. Penelitian ini juga dapat digunakan sebagai bahan pertimbangan guru SD untuk dapat menentukan pendekatan yang tepat dalam melaksanakan pembelajaran menulis di SD.Tindakan kelas dilakukan sebanyak dua siklus. Subjek penelitian adalah siswa kelas V SDN 04 Karet Setiabudi Jakarta Selatan. Pengumpulan data dilakukan melalui observasi dan tes menulis narasi. Hasil penelitian ini menunjukkan bahwa penerapan pendekatan kontekstual dengan variasi metode dan alat bantu yang tepat dapat meningkatkan kemampuan menulis narasi siswa kelas V SD.

Kata Kunci: menulis, pendekatan kontekstual, sekolah dasar.

PENDAHULUAN Manusia sebagai mahluk sosial cenderung hidup berkelompok, sehingga dalam hidup berkelompok itu manusia satu dengan yang lain saling berkomunikasi. Alat komunikasi yang paling efektif adalah bahasa. Mulai dari lingkup sosial yang paling kecil, yaitu keluarga sampai organisasi kemasyarakatan yang paling besar menggunakan bahasa sebagai alat komunikasi.

Di dalam dunia pendidikan, bahasa juga memegang peranan sangat penting. Hampir pada setiap lembaga pendidikan di negara mana saja bahasa menjadi salah satu inti kurikulum. Demikian halnya kurikulum pendidikan di Indonesia juga menempatkan bahasa Indonesia sebagai mata pelajaran utama.

Pembelajaran bahasa Indonesia di SD meliputi empat aspek yaitu keterampilan menyimak, keterampilan berbicara, keterampilan membaca dan keterampilan menulis.

Keterampilan menulis sebagai salah satu aspek keterampilan berbahasa merupakan tahapan akhir yang dikuasai siswa, karena siswa dapat menulis dengan baik apabila serangkaian tahapan aspek keterampilan berbahasa telah dikuasai siswa. Sehingga diharapkan pada akhirnya siswa dapat memenuhi standar kompetensi kemampuan berbahasa dalam aspek menulis yaitu menulis secara efektif dan efisien berbagai jenis karangan dalam berbagai konteks.

Untuk dapat menulis secara efektif dan efisien bukanlah hal yang mudah, sebab diperlukan serangkaian proses yang panjang. Proses tersebut akan dijalani oleh siswa melalui tahapan-tahapan dalam pembelajaran bahasa. Salah satu tahapan pembelajaran menulis adalah 
menulis lanjutan yaitu menulis karangan. Menulis karangan selama ini masih sering dianggap beban yang berat bagi siswa, karena dianggap sulit.

Dalam pembelajaran bahasa Indonesia anak akan dapat menulis dengan baik jika ia telah memiliki keterampilan membaca (Hayon, 2003). Jika siswa belum memiliki keterampilan membaca, siswa belum mampu mengungkapkan isi pikiran secara tertulis.

Sejak masa balita anak sudah mulai pandai bercerita atau berbicara, seperti berbicara tentang peristiwa yang dialami sehari-hari. Hal itu mengindikasikan bahwa anak telah mempunyai kemampuan mengungkapkan isi pikirannya dengan bahasa secara lisan. Jika siswa telah mampu bercerita secara lisan maka untuk mengarang tidak sulit, karena tinggal menuangkan ke dalam bahasa tulisan. Karena pada hakikatnya bahasa tulis merupakan suatu jenis perekaman bahasa lisan (Hayon, 2003:93).

Namun pada kenyataan di lapangan menunjukkan tingkat keberhasilan menulis karangan pada siswa SD masih rendah. Banyak ditemui di kelas V SD 04 Karet Setiabudi Jakarta Selatan, siswa pandai bercerita tetapi ketika ditugasi menulis, siswa tersebut belum dapat mengungkapkan cerita tersebut secara tertulis atau menuangkan dalam bahasa tulis. Kalaupun ada beberapa siswa yang telah mampu mengungkapkan ide-ide dalam bentuk tulisan, tetapi kalimat-kalimatnya masih kacau, belum tersusun secara efektif seperti pengulangan kata, kalimat dan lainnya.

Dari pihak guru, tampaknya sebagian besar guru masih belum dapat menciptakan suasana belajar yang kondusif khususnya dalam pembelajaran menulis. Pendekatan yang digunakan guru dirasakan kurang pas dalam pembelajaran menulis. Guru cenderung memberi contoh dan instruksi, kemudian siswa mengikuti contoh dan instruksi dari guru, yang terkadang contoh itu didapat hanya dari buku paket.

Berbagai cara dapat dilakukan untuk kegiatan menulis karangan, yang memacu kreativitas dan motivasi siswa. Di antaranya menonton pertunjukan, menikmati gambar/dokumentasi, karya wisata, perayaan ulang tahun, kegiatan lomba dan lain-lain. Dari aktivitas itu, guru dapat mengondisikan siswa agar mengangkat kegiatan tersebut sebagai sumber inspirasi dalam menulis karangan, melalui berbagai pendekatan.

Sehubungan dengan hal tersebut di atas, maka pendekatan yang memungkinkan untuk memenuhi tuntutan persoalan di atas adalah pendekatan kontekstual. Melalui pendekatan kontekstual guru dapat mengaitkan materi yang diajarkan dengan kehidupan nyata anak. Dalam pendekatan kontekstual, siswa dapat dikondisikan dalam kelompok kecil atau masyarakat belajar (learning community), sehingga mereka dapat berlatih berkomunikasi apa-apa yang telah diketahuinya, tanpa merasa terbebani.

Dalam rangka meningkatkan kemampuan menulis siswa SD kelas tinggi khususnya, maka diperlukan kajian ilmiah, antara lain melalui penelitian tindakan. Penelitian ini diharapkan dapat berdampak positif terhadap peningkatan kemampuan siswa dalam menulis narasi. Salah satu pendekatan yang penulis coba untuk dilaksanakan adalah pendekatan kontekstual dengan metode yang variatif dalam pembelajaran menulis di kelas V SD.

Menulis di sini sama dengan mengarang. Menulis merupakan keseluruhan rangkaian kegiatan seseorang dalam mengungkapkan gagasan dan menyampaikan bahasa tulis kepada pembaca untuk dipahami dan dimengerti oleh orang lain (Gie,1992:17). Dalam konteks ini menulis adalah kegiatan komunikasi yang dilakukan sendiri tanpa didukung oleh tekananan suara, nada, nada, mimik dan gerakgerik seperti komunikasi lisan.

Kemampuan menulis hakikatnya adalah mengembangkan keterampilan menulis kreatif. Dikatakan demikian karena yang akan dijadikan fokus dalam penelitian ini adalah menulis cerita (narasi), yakni cerita narasi atau yang lebih populer dengan sebutan fiksi (cerita rekaan). Jenis cerita fiksi dapat dikembangkan berdasarkan dua sumber, yaitu imajinasi dan fakta. Menurut Thahar (2008:2) "imajinasi adalah cerita yang ditulis berdasarkan hasil khayalan penulisnya. Fakta adalah cerita yang bersumber dari pengalaman nyata penulisnya." Jadi, kemampuan menulis memerlukan latihan terus menerus, sehingga penulis memahami apa yang akan ditulis, dan kemampuan menulis bukan bakat, bukan bawaan sejak lahir atau warisan, tetapi kemampuan itu dimiliki seeorang melalui 
belajar dan latihan yang terus-menerus dikembangkan (Lorch, 1984:7). Jadi kemampuan menulis di sini merupakan kesanggupan siswa dalam menulis sesuatu bersumber dari pengalaman nyata penulisnya.

Narasi merupakan menulis kreatif. Kreatif adalah kata sifat. Jadi menulis kreatif (creative writing) artinya tulisan yang berupa hasil ciptaan seseorang yang sifatnya baru, atau yang belum ada sebelumnya, karena kreatif adalah kemampuan mencipta sesuatu yang baru.

Narasi merupakan tulisan yang bercerita, kejadian dirangkai secara runtut menurut alur waktu (kronologis). Marahimin (1994:8) mengungkapkan bahwa narasi yaitu karangan yang didasarkan pada urutan/rangkaian kejadian /peristiwa secara berurutan. Keraf (Baharuddin \& Wahyuni, 2007) menyatakan bahwa narasi adalah bentuk wacana yang berusaha menggambarkan dengan jelas kepada pembaca suatu peristiwa yang telah terjadi yang dijalin dalam satu kesatuan waktu. Jadi menulis narasi merupakan kegiatan seseorang dalam menuangkan ide-idenya secara runtut yang bersumber dari pengalaman nyata penulisnya serta diungkap sesuai dengan urutan atau kejadian peristiwa.

Kemampuan menulis narasi di sini merupakan keterampilan siswa dalam mengomunikasikan dengan baik tentang sesuatu fakta yang pernah dialami yang baru dan bersumber dari pengalaman nyata penulisnya, dan disampaikan secara runtut menurut alur waktu (kronologis), dengan menggunakan tokoh, latar, dan ditulis dengan menggunakan ejaan yang benar, kosa kata yang variatif dan kalimat yang baik, bahasa yang jelas, sehingga dapat dipahami oleh pembaca.

Pendekatan kontekstual adalah salah satu aliran filsafat yang mempunyai pandangan bahwa siswa mampu menyerap pelajaran apabila mereka dapat menangkap makna dalam materi yang mereka terima dan dapat mengaitkan informasi baru dengan pengetahuan dan pengalaman yang sudah mereka miliki (Johnson, 2006:14). Selanjutnya Johnson juga mengukap bahwa belajar secara kontekstual berarti mengeluarkan potensi penuh seorang siswa secara alamiah.

Pendapat lain mengatakan bahwa pendekatan kontekstual mempunyai tujuan membantu guru mangaitkan materi yang diajarkan dengan situasi dunia nyata siswa dan mendorong siswa memembuat hubungan antara pengetahuan yang dimilikinya dengan penerapannya dalam kehidupan mereka sehari-hari (Nurhadi, 2003:1). Pendekatan kontekstual berusaha menghadirkan dunia nyata ke dalam kelas. Karakteristik pembelajaran kontekstual adalah kerjasama, saling menunjang, pembelajaran terintegrasi, menggunakan berbagai sumber, siswa aktif, tukar pendapat dengan teman, siswa kritis, guru kreatif, di dinding kelas dan lorong-lorong penuh dengan hasil karya. Zahorik (Nurhadi, 2003:3) mengatakan, pendekatan kontekstual (Contextual Teaching And Learning / CTL) adalah Knowledge is constructed by humans. Knowledge is not a set of facts, concepts, or low waiting tube discovered. Its is not something that exists independent of a knower. Humans create or construct knowledge or as they attempt to bring meaning go their experience. Everything that we know, we have made. Jadi dalam hal ini kontekstual dapat dikatakan sebagai makna, bermakna, dan dibermaknakan, maksudnya; guru berperan sebagai fasilitator (reinforcing), yakni membantu siswa menemukan makna (pengetahuan). Makna di sini adalah makna dari materi yang diajarkan. Maksudnya menghubungkan materi ajar dengan lingkungan personal/sosial.

Dari beberapa pendapat di atas bahwa pendekatan kontektual dalam penelitian ini adalah proses belajar yang melibatkan siswa secara aktif dan guru sebagai fasilitator dengan menghubungkan materi ajar dengan konteks kehidupan nyata dengan menggunakan berbagai metode yang mengoptimalkan pembimbingan baik individual, kelompok maupun klasikal yang sesuai dengan kondisi yang diperlukan.

Dalam pembelajaran kontekstual pada penelitian ini diimplementasikan langkahlangkah berikut: (1) membuat hubungan yang bermakna (making meaningfull onnections) antara sekolah dengan konteks kehidupan nyata, (2) melakukan pekerjaan yang signifikan (doing significant), pekerjaan yang memiliki tujuan, kepedulian terhadap orang lain dan meghasilkan produk, (3) pembelajaran mandiri (self regulated learning) yang membangun minat individu untuk bekerja dalam rangka menapai tujuan yang bermakna dengan mengaitkan materi ajar dan konteks kehidupan sehari-hari, (4) bekerjasama 
(collaborating) untuk membantu siswa bekerja secara efektif dalam kelompok, (5) berpikir kritis dan kreatif (critical anda creative thingking), siswa diwajibkan untuk memanfaatkan berpikir kritis dan kreatif, (6) pendewasaan individu (nurturing individual) dengan mengenalnya, memberikan perhatian, mempunyai harapan yang tinggi terhadap siswa dan memotivasinya, (7) pencapaian standar yang tinggi (reaching high standards) melalui pengidentifikasian tujuan dan motivasi siswa untuk mencapaianya, (8) menggunakan penilaian autentik (using authentic assessment) yang menantang siswa agar menggunakan informasi akademis baru dan keterampilannya ke dalam situasi nyata untuk tujuan yang signifikan membentuk group belajar yang saling bergantung (interdependent learning groups), dan (9) penerapan pembelajaran kontekstual untuk melaksanakan hal di atas dalam pembelajaran menulis narasi.

Implikasi pendekatan kontektual seperti ini menjadi tugas guru untuk membantu siswa mencapai tujuannya, dengan maksud guru lebih banyak merancang strategi daripada pemberian informasi bahan pelajaran.

\section{METODE}

Penelitian ini merupakan penelitian tindakan. Tujuannya (1) untuk meningkatkan kemampuan menulis karangan narasi siswa kelas V SD. Dan (2) memperoleh data kongkret apakah pendekatan kontekstual dapat meningkatkan kemampuan menulis narasi siswa kelas V SD 04 Karet Setiabudi Jakarta Selatan. Pada penelitian ini peran dan posisi peneliti adalah sebagai guru/pengajar dan sekaligus sebagai peneliti.

Mengacu pada model penelitian tindakan yang dikembangkan oleh Kemmis dan McTaggart (1988:10), penelitian ini terdiri atas: penjajagan awal, perencanaan, tindakan dan pengamatan/refleksi pada siklus pertama, dilanjutkan ke siklus kedua. Kegiatan perencanaan pada siklus pertama dan seterusnya mencakup identifikasi masalah, rumusan masalah dan merancang program tindakan. Pelaksanaan tindakan dan pengamatan, dilakukan pada saat pelaksanaan pembelajaran di kelas.

Sebelum melaksanakan penelitian tindakan ini, dipersiapkan hal-hal yang dapat memperlancar jalannya penelitian ini, yaitu melakukan langkah sebagai berikut:

1) Melakukan observasi awal dan sosialisasi rancangan penelitian dengan guru kelas V SD serta mahasiswa SI PGSD yang akan dilibatkan sebagai kolabulator/pengamat.

2) Menyusun perencanaan pembelajaran dan pembagian tugas antara peneliti dengan guru kelas V dan guru kelas IV sebagai kolabolator serta mahasisiswa SI PGSD.

3) Menyosialisasikan tugas.

4) Menyusun skenario pembelajaran yang menggunakan pendekatan kontekstual dengan metode dan media yang bervariasi.

5) Mempersiapkan alat bantu pembelajaran.

6) Merencanakan jadwal pertemuan dan jadwal pelaksanaan tindakan secara priodik bersama guru mitra untuk melakukan refleksi.

Seluruh rencana kegiatan di atas ditetapkan bersama secara musyawarah antara peneliti dan kolabulator, sesuai dengan prinsip penelitian tindakan kelas, yaitu tidak mengganggu tugas pokok guru sebagai guru kelas.

Data yang digunakan dalam penelitian ini adalah data yang menggambarkan keberhasilan penelitian. Adapun data penelitian terdiri atas (a) data kuantitatif (data hasil), yakni data hasil tes menulis narasi dan data (b) kualitatif (data proses). Data kuantitatif diperoleh dari hasil tes menulis narasi yang terdiri atas tes pra-tindakan, tes akhir siklus dan postes. Sedangkan data kualitatif adalah data yang mendeskripsikan proses pembelajaran yang dilakukan oleh para observer. Instrumen pengumpul data yang digunakan dalam penelitian ini adalah tes tertulis, observasi, diperkuat dengan catatan lapangan hasil observasi yang dilakukan observer. Kemmis dan McTaggart (1988:100) menyatakan bahwa teknik pengumpulan data yang dapat digunakan dalam penelitian tindakan adalah catatan anekdot, catatan lapangan, deskripsi perilaku ekologis, analisis dokumen, portofolio, angket, wawancara, foto, slide dan tes kemampuan siswa. Berdasarkan pernyataan Kemmis dan McTaggart ini maka peneliti menggunakan tes, observasi (rekaman video) dan fortofolio. Data kemudian diorganisasikan secara sistematis dan rasional. Adapun tahapan dalam analisis data antara lain (1) penyederhanaan melalui seleksi, pemokusan, dan pengabstraksian data mentah hingga jadi 
bermakna; (2) pemaparan dalam bentuk naratif, representasi grafis dan sebagainya; dan (3) penyimpulan.

\section{HASIL}

\section{Identifikasi Aspek- Aspek Menulis}

Peneliti mengidentifikasi aspek-aspek menulis dari data yang didapat sesuai komponen dalam keterampilan mengungkapkan ide/gagasan atau isi tulisan, keterampilan mengorganisasi tulisan sesuai narasi (secara kronologis (awal cerita, konflik-konflik/peristiwa dan akhir cerita, pengungkapan cerita melalui tokoh), pengungkapan bahasa yang dapat dipahami (struktur kalimat dan kata) yang baik, penulisan dengan tata tulis yang benar yang sesuai dengan pedoman dalam ejaan yang benar.

Berikut ini akan dikemukakan hasil pengamatan dalam proses pembelajaran melalui pendekatan konstruktivisme:

\section{Keterampilan Mengungkapkan Ide sesuai Karakteristi \\ Narasi}

Hasil pengamatan selama proses pembelajaran dan hasil tes menunjukkan bahwa kesulitan siswa dalam mengungkapkan ide secara tertulis sangat menonjol. Banyak siswa yang dapat bercerita secara lisan dengan baik, tetapi ketika ditugasi menuliskannya, mereka merasa sulit. Hal ini terjadi karena terbatasnya pengetahuan siswa akan struktur kalimat yang baik dan kosakata yang masih sangat terbatas. Untuk mengatasi ini, peneliti membimbing siswa dengan cara memberi pertanyaan pancingan, menunjukkan situasi, alat, gambar peristiwa, contoh/model cerita narasi, sehingga dapat menuntun siswa untuk mengaktualisasikan ideide/ pikiran yang sesuai karakteristik narasi yang sebenarnya telah mereka ketahui, namun masih terpendam. Sehingga, ide yang tersumbat menjadi terbuka secara bertahap.

Upaya meningkatkan keterampilan mengungkapkan ide ini merupakan bagian yang sangat strategis bagi siswa sekolah dasar untuk terampil menulis. Dikatakan demikian, karena jika ide siswa sudah muncul, maka kegiatan menulis akan lancar.

\section{Keterampilan Organisasi Narasi}

Dalam meningkatkan keterampilan ini, peneliti menemukan bahwa siswa mengalami kesulitan mengurutkan cerita secara teratur (kronologis). Konflik-konflik ditulis secara terpisah, belum ada kata hubung (belum koheren).

Siswa pada umumnya belum memahami bagaimana memulai cerita, bagaimana menyajikan konflik-konflik dan bagaimana akhir cerita. Karena itu peneliti selalu memberi bimbingan, misalnya; "Tamasya Ke Ancol". Dalam menceritakan dapat dimulai dari urutan waktu "Hari itu pukul 7.00 pagi. Andi, Toto dan Dini telah bersiap-siap untuk pergi tamasya....dst. Banyak siswa yang mengungkapkan cerita melompat-lompat sesuai dengan apa yang diingatnya. Misalnya: "Aku ke Ancol, terustu ke pantai." ..Aku senang melihat ikan besar-besar di aquarium gede...." Untaian cerita itu belum berurut, tetapi melompat-lompat sesuai dengan apa yang diingatnya. Kalimat Apa yang diingatnya cenderung sesuatu yang menarik perhatiannya, misalnya 'ikan gede-gede' di Ancol (narasi yang ditulis, dimulai dari aku ke Ancol). Dari ide awal tersebut, peneliti membimbing dengan pertanyaan "Kapan kamu ke Ancol?, Dengan kendaraan apa? Bersama siapa?, dst." Siswa dibimbing dalam mengungkapkan cerita (narasi) sehingga siswa dapat menyampaikan secara berurut, dari awal, selanjutnya setelah itu apa, berikutnya... dan sampai cerita tersebut berakhir. Dari temuan ini peneliti memberi bimbingan dengan pertanyaan pancingan; Siswa disuruh menjawab pertanyan pancingan, kemudian siswa dibimbing menuliskannya dengan baik, dan diberi contoh. Dengan demikian, siswa akan mengorganisasikan ceritanya secara berurut.

Dalam situasi seperti ini, guru harus sabar, membuat suasana lebih rileks dan bersahabat, tetapi tegas. Jika tidak tegas, siswa cenderung bermain-main dan kurang tanggung jawab.

\section{Kompetensi Kebahasaan}

Hal yang perlu dikembangkan dalam menulis narasi atau karangan secara umumnya adalah keterampilan membuat kalimat dan memilih kata yang sesuai dengan konteks. Dengan demikian maka ide/ ungkapan pikiran yang 
menjiwai tulisan tersebut dapat dipahami oleh pembaca.

Kebahasaan dalam penelitian ini adalah tata bahasa yang sesuai dengan psikologis siswa kelas V, kalimatnya masih sederhana (tidak berbelit-belit). Demikian pula dengan kosa kata, masih kosa kata dasar, kosa kata jadian yang masih sederhana, belum kata kompleks, namun sesuai dengan konteksnya. Jadi ukuran kebahasaan masih belum begitu dalam dan luas. Namun penekanan agar siswa tidak selalu menggunakan kata yang sama yang berulangulang (klise).

Dalam penelitian ini, peneliti menemukan siswa masih banyak menggunakan kata yang berulang-ulang, serta penulisan kata yang kurang lengkap. Misalnya kata penghubung kalimat "dan-dan, dan, dari itu , terustu, maksudnya selanjutnya" padahal banyak kata hubung lain yang dapat digunakan. Selanjutnya kata "rumah" banyak yang menulis "ruma".

Untuk mengatasi hal ini, peneliti memberi contoh melalui membacakan contoh cerita, diberi penegasan ketika ditemukan kata hubung, katakata yang sejenis dengan kesalahan siswa dipertegas untuk diperhatikan. Jangan sekali-kali mengatakan kata "ini salah" (menyalahkan siswa), karena hal ini menurut pengamatan peneliti, berdampak pada motivasi siswa menjadi menurun dalam menyelesaikan tugas/karyanya.

\section{Keterampilan Menggunakan Tata Tulis}

Hal yang perlu dikembangkan dalam keterampilan menggunakan ejaan meliputi penulisan huruf, pemakaian huruf, dan penggunaan tanda baca. Hal ini perlu ditegaskan kepada siswa bahwa kesalahan satu huruf (fonem) saja bisa bermakna lain. Misalnya, ketika siswa menuliskan "Gaji ayahku naik." Kata gaji ditulis 'gajih'. selain itu siswa masih banyak yang belum bisa menggunakan tanda koma (,) di antara unsur-unsur atau perincian dan tanda koma untuk memisah kata, seperti; O, begitu? Dan lain-lain. Untuk mengatasi hal ini, guru memberi contoh langsung, dengan cara menunjukkan penggunaannya dalam konteks, atau menuliskannya di papan tulis, serta menunjukkan contoh pengunaan tanda baca tersebut yang digantung di dinding.

Untuk melihat peningkatan keterampilan menulis siswa dalam setiap aspek tersebut, peneliti pun mengelompokkan data hasil menulis berdasarkan setiap aspek yang mendukung katerampilan menulis, yang dikemukakan dalam tabel berikut ini:

Hasil Menulis Narasi

\begin{tabular}{|c|c|c|c|c|c|}
\hline Siklus & Isi / Gagasan & $\begin{array}{c}\text { Organisasi } \\
\text { (narasi) }\end{array}$ & Tata Bahasa & EYD & $\begin{array}{c}\text { Jumlah Skor/ } \\
\text { NA }\end{array}$ \\
\hline Pree tes & 24,33 & 16,54 & 10,45 & 2,82 & 54,14 \\
I & $29,3 \%$ & $21,6 \%$ & $14,8 \%$ & $6,9 \%$ & $72,6 \%$ \\
II & $32,0 \%$ & $24,2 \%$ & $16,8 \%$ & $7,3 \%$ & $80,2 \%$ \\
Postes & 32,03 & 24,57 & 17,11 & 7,40 & 81,11 \\
\hline
\end{tabular}

\section{PEMBAHASAN}

Dari rangkaian pengujian yang dilakukan oleh peneliti ditemukan beberapa hal tentang pembelajaran menulis narasi. Pembelajaran menulis narasi dapat meningkat, jika guru mampu melaksanakan pembelajaran dengan menggunakan pendekatan, metode, strategi yang variatif, yang sesuai dengan kecenderungan/karakteristik siswa sekolah dasar. Selain itu, guru harus mengoptimalkan penggunaan sarana/alat bantu pembelajaran sesuai dengan pendekatan yang dirancang dengan tepat.
Pembelajaran menulis dengan pendekatan kontekstual, merupakan salah satu pendekatan yang tepat untuk meningkatkan kemampuan menulis karangan (narasi) pada siswa kelas tinggi sekolah dasar. Dengan pendekatan ini siswa dihadapkan pada hal-hal menantang dan berhubungan dengan kehidupan sehari-hari secara nyata, atau dengan kata lain, memberdayakan apa-apa yang telah diketahui siswa, seperti apa yang telah dialami. Siswa diberi kesempatan untuk menghubungkan pokok bahasan/materi dengan dunia nyata yang diintegrasikan dengan pengetahuan siswa, dan 
diaktualisasikan dengan menggunakan bahasa Indonesia yang baik sebagai media.

Kondisi pembelajaran harus diciptakan melalui komunikasi yang berterima bagi siswa. Berterima di sini maksudnya, dengan memilih diksi yang pas, intonasi yang yang bersahabat dan dikemas dalam situasi pembelajaran yang mengondisikan siswa dalam situasi belajar yang menyenangkan. Alat bantu/strategi pembelajaran dapat dilakukan dengan memperlihatkan gambar-gambar objek yang telah mereka kenal, diajak mengamati buku-buku cerita sebagai model, dan bekerja dalam kelompok, sehingga tercipta komunikasi antarsesama teman sehingga memancing ide-ide dan menambah perbendaharaan kata.

Selanjutnya, kegiatan menulis karangan disertai kegiatan yang menyenangkan, yang dekat dengan dunia anak. Hal ini antara lain, dengan pemodelan yang beragam untuk meningkatkan minat siswa dalam menulis. Kondisi ini tampak dapat mendorong keingintahuan siswa agar terampil menciptakan karya yang berupa cerita seperti model yang disajikan, yang dimulai siswa dengan bertanya.

Selain itu, siswa lebih lancar menuliskan kesan yang didapat, dari pengalamannya, melalui arahan dengan pertanyaan pancingan. Dengan cara itu, siswa dapat lebih berani mengungkapkan ide/gagasan yang ingin diungkapkan.

Dari serangkaian model yang digunakan oleh peneliti ternyata menunjukkan kebermaknaan yang khas dari masing-masing model. Model gambar/foto, membantu mengingatkan anak akan pengalaman yang telah lalu, ditambah dengan pencingan pertanyaan-pertanyaan.

Model gambar hidup lebih membangkitkan siswa untuk bertanya hal-hal yang belum dipahami, dan membantu siswa dalam mengurutkan peristiwa dalam cerita (kronologis), dan keterampilan menggunakan kosa kata lebih berkembang.

Sedangkan model kontekstual, dengan mengajak siswa mengunjungi tempat umum, seperti pasar tradisional sangat dekat dengan dunia anak, sehingga anak lebih bebas mengekspresikan perasaan tentang peristiwa yang dilihat/dalam imajinasinya dengan menggunakan kata-kata sehari-hari.
Jika kemampuan menuangkan ide atau gagasan pada siswa sudah muncul dan perbendaharaan kata sudah banyak, maka teknik penulisan paragraf dan penulisan huruf yang benar, dijelaskan kembali, diberi contoh pemakaiannya secara nyata seperti menempel contoh-contoh huruf dan tanda baca yang benar di dinding. Dengan demikian, diharapkan katerampilan siswa dalam menulis narasi dapat mencapai hasil yang optimal.

Namun, dibalik peningkatan yang di dapat, satu sisi yang belum bisa ditingkatkan adalah memperbaiki bentuk tulisan siswa. Bentuk tulisan siswa beraneka ragam, ada yang menggunakan huruf cetak, huruf tulis tegak yang dicampur dengan cetak, dan sebagian kecil huruf miring yang dicampur huruf pisah. Ukuran tulisan siswa pun masih belum tertib. Ada yang dua kolom, satu kolom dan sebagainya.

Untuk mengatasi hal ini, tampaknya tidak dapat diperbaiki dalam satu smester, tetapi memerlukan pembinaan yang terus menerus oleh guru SD, mulai dari menulis permulaan di kelas rendah, dan dilanjutkan dalam menulis lanjut oleh guru kelas tinggi .

Selain itu, yang perlu diingat, bahwa kegiatan menulis, bukan saja dalam pelajaran bahasa Indonesia, tetapi terintegrasi dalam semua mata pelajaran atau pada setiap kesempatan menulis dalam pelajaran apapun.

\section{SIMPULAN}

Berdasarkan pengamatan selama dua siklus dan pembahasan hasil penelitian tindakan ini, dapat dikemukakan beberapa simpulan sebagai berikut:

Pada bagian pertama dari simpulan akan dikemukakan hal-hal yang berhubungan dengan masalah penelitian tentang proses yakni: "Bagaimanakah meningkatkan keterampilan menulis narasi siswa kelas V SD melalui pendekatan kontekstual?"

Untuk meningkatkan keterampilan menulis narasi siswa kelas tinggi sekolah dasar (kelas V) di Sekolah Dasar Latihan PGSD Fakultas Ilmu Pendidikan Universitas Negeri Jakarta Melalui pendekatan kontekstual, diimplementasikan melalui langkah-langkah seperti berikut ini:

Pertama: Menerapkan strategi; (1) Topdownprocessing; pembelajaran dimulai dari 
masalah kompleks untuk dipecahkan, kemudian menggali keterampilan yang dibutuhkan; (2) Cooperative learning; siswa diberi kesempatan untuk berdiskusi dengan siswa lain tentang suatu problem. Siswa belajar dalam kelompok untuk saling membantu memecahkan masalah yang dihadapi. Melalui kelompok sosial belajar ini siswa mendapatkan pengetahuan, mengeksplorasi pengetahuan; (3) Generative Learning; menekankan pada integrasi yang aktif antara materi atau pengetahuan yang baru diperoleh dengan skemata, sehingga siswa mampu beradaptasi ketika menghadapi stimulus baru. Dalam strategi ini, siswa dilatih memecahkan masalah, menemukan sesuatu yang berguna, dan mengembangkan ide-ide. siswa dilatih mengonstruksi pengetahuan yang ada di benaknya, dan mentransformasikan suatu informasi kompleks ke situasi lain.

Kedua: Penerapan strategi pembelajaran dengan memberi feedback langsung dan menantang yang mengacu pada pendekatan kontekstual yang berupa pernyataan positif dan komunikatif yang diberikan kepada siswa yang memerlukannya, misalnya siswa yang tampak masih kesulitan dalam mengembangkan isi tulisannya, maka guru mengajukan pertanyaan " Coba lihat, baca pelan-pelan, sudah itu apa lagi yang terjadi ?." Cara ini, dapat meningkatkan motivasi dan kreativitas siswa dalam mengembangkan tulisan.

Ketiga: Mencermati hasil menulis narasi pada siklus kedua, yakni katerampilan siswa dalam aspek pengembangan gagasan masih belum mencapai target yang diharapkan. Kondisi ini disebabkan siswa kurang konsentrasi dan kurang terfokus dengan apa yang telah mereka tulis pada pertemuan sebelumnya. Konsentrasi para siswa menjadi terputus, ide-ide seolah-olah bercerai -berai sehingga memerlukan waktu dan strategi untuk menjadikan siswa dapat melanjutkan tulisannya pada pertemuan lanjutan. Karena itu, maka strategi yang tepat untuk memberi kesempatan kepada siswa menulis dalam waktu yang berkesinambungan tanpa terputus. Guru harus menciptakan situasi yang menyenangkan, yang menggiring siswa untuk menuangkan ide-ide / tulisan narasi secara utuh. Karena dikhawatirkan dengan waktu yang panjang akan memunculkan rasa bosan. Untuk itu, maka strategi pembelajaran menulis dilaksanakan dalam satu kesempatan (pada waktu yang panjang), namun diiringi dengan instrument lagu, dan penataan kelas yang variatif. Maka peneliti/tim kolabulator menerapkan prinsif-prinsif pembelajaran konstruktivisme dalam discovery learning, contextual teaching and learning dan strategi advance organizer.

Strategi Advance Organization dan pemberian model serta bimbingan secara bertahap yang dilaksanakan secara berkesinambungan memberikan dampak sangat positif, dekat dengan dunia anak. Dengan strategi ini perhatian siswa menjadi terfokus, perhatian siswa menjadi meningkat dan bergairah dalam mengikuti kegiatan menulis narasi.

Strategi dialog, penguatan spontan dan ikhlas dapat membangkitkan motivasi dan keberanian dan rasa percaya diri siswa untuk berkarya.

Temuan yang paling menarik, adalah strategi dalam mengatasi kebosanan siswa, yakni dilakukan dengan cara memperdengarkan lagu instrumental, ketika siswa sedang bekerja/ mengembangkan tulisan narasi dan dilanjutkan dengan siswa mencoba memersiapkan tulisan untuk dipublikasikan. Tampak tidak ada satu pun siswa yang mengantuk, lemas, atau bermain-main dengan kawannya. Khusus untuk memperbaiki bentuk tulisan siswa, tampaknya tidak dapat dilakukan dalam waktu cepat, tetapi menurut pengamatan peneliti, bentuk tulisan siswa, dapat diperbaiki melalui pembinaan yang berkesinambungan sejak kelas awal sekolah dasar dan dilanjutkan sampai kelas tinggi ( kelas IV, V dan VI). Guru kelas tinggi sekolah dasar perlu ikut peduli terhadap perbaikan bentuk tulisan siswa SD.

Simpulan bagian kedua, akan dikemukakan hasil temuan yang berhubungan dengan masalah penelitian kedua yakni: "Apakah pendekatan konstruktivisme dapat meningkatkan keterampilan menulis narasi siswa kelas $\mathrm{V}$ sekolah Dasar?"

Berdasarkan uraian yang dikemukakan pada bab IV, diketahui bahwa "Melalui pendekatan kontekstual, terbukti bahwa keterampilan siswa dalam menulis narasi meningkat." Peningkatan itu terjadi pada setiap siklus. Persentase peningkatan keterampilan menulis yang diperoleh siswa dalam setiap siklus (siklus 
pertama ke siklus kedua), dapat dilihat pada tabel hasil penelitian.

Dengan demikian, maka dugaan awal (hipotesis) penelitian yakni: "Jika pembelajaran menulis narasi di kelas V SD diberikan dengan pendekatan kontekstual dengan metode, strategi dan alat bantu yang bervariasi, maka keterampilan menulis narasi siswa kelas V SDN 04 Karet Setiabudi akan meningkat".

\section{REFERENSI}

Baharuddin \& Wahyuni, Esa Nur. (2007). Teori Belajar dan Pembelajaran. Yogyakarta: ArrRuzz Media.

Gie, Liang. (1992). Pengantar Dunia karang Mengarang. Jogyakarta: Liberty.

Hayon, Yosep. (2003) Membaca dan Menulis Wacana. Jakarta: Storia Grafika.
Johnson, Elaine B. (2006). Contxtual Teaching $\mathcal{E}$ Learning. Bandung: Mizan Learning Center (MLC).

Kemmis, and Robin, McTaggart. (1988). The Action Research Planner. Deak versity Press.

Lorch, Sue. (1984). Basic Writing: Practical Approach, Second Edition. Boston: Brown and Company.

Marahimin, Ismail. (1994). Menulis Secara Populer, Jakarta: Pustaka Jaya.

Nurhadi. (2003). Pendekatan Kontekstual (Contekstual Teaching and Learning). Jakarta: Departemen Pendidikan Nasional, Dirjendikdasmen.

Thahar, Harris Effendi. (2008). Menulis Kreatif. Padang: UNP Press. 